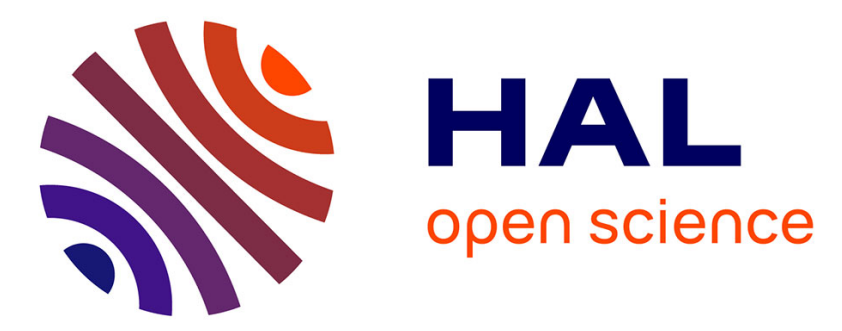

\title{
Mosaic 15q13.3 deletion including CHRNA7 gene in monozygotic twins.
}

Cornel Popovici, Tiffany Busa, Chantal Missirian, Mathieu Milh, Anne

Moncla, Nicole Philip

\section{- To cite this version:}

Cornel Popovici, Tiffany Busa, Chantal Missirian, Mathieu Milh, Anne Moncla, et al.. Mosaic 15q13.3 deletion including CHRNA7 gene in monozygotic twins.: Mosaic 15q13.3 deletion including CHRNA7 gene in MZ twins. European Journal of Medical Genetics, 2013, 56 (5), pp.274-7. 10.1016/j.ejmg.2013.02.005 . inserm-00799062

\section{HAL Id: inserm-00799062 https://www.hal.inserm.fr/inserm-00799062}

Submitted on 11 Mar 2013

HAL is a multi-disciplinary open access archive for the deposit and dissemination of scientific research documents, whether they are published or not. The documents may come from teaching and research institutions in France or abroad, or from public or private research centers.
L'archive ouverte pluridisciplinaire HAL, est destinée au dépôt et à la diffusion de documents scientifiques de niveau recherche, publiés ou non, émanant des établissements d'enseignement et de recherche français ou étrangers, des laboratoires publics ou privés. 


\section{Chromosomal imbalance letters}

\section{Mosaic 15q13.3 deletion including CHRNA7 gene in monozygotic twins}

Cornel Popovici ${ }^{1,2}$, Tiffany Busa ${ }^{3,4}$, Chantal Missirian ${ }^{1,3}$, Mathieu Milh ${ }^{2,5}$, Anne Moncla $^{1,3,4}$ and Nicole Philip ${ }^{2,3,4}$

${ }^{1}$ Laboratoire de Génétique Chromosomique, Département de Génétique Médicale, Hôpital Timone - Enfants, Assistance Publique - Hôpitaux de Marseille, Marseille, France

${ }^{2}$ INSERM UMR S910 "Génétique Médicale \& Génomique Fonctionnelle », Marseille, France

${ }^{3}$ Unité de Génétique Clinique, Centre de Référence « Anomalies du Développement et Syndromes Malformatifs Sud-Est PACA », Département de Génétique Médicale, Hôpital Timone - Enfants, Assistance Publique - Hôpitaux de Marseille, Marseille, France

${ }^{4}$ Faculté de Médecine, Aix Marseille Université, Marseille, France

${ }^{5}$ Service de Neurologie Pédiatrique, Hôpital Timone - Enfants, Assistance Publique - Hôpitaux de Marseille, Marseille, France

Running title: Mosaic 15q13.3 deletion including CHRNA7 gene in MZ twins

Key Words: 15q13.3 deletion, mosaicism, CHRNA7, twins 
Corresponding author:

Cornel Popovici, MD, PhD

Laboratoire de Génétique Chromosomique

Département de Génétique Médicale

Hôpital Timone - Enfants

Assistance Publique - Hôpitaux de Marseille

264 Rue Saint-Pierre

13885 Marseille cedex 05

Phone: +33 491384796

Fax: +33491384604

E-mail: cornel.popovici@ap-hm.fr 


\section{Abstract}

Deletions in $15 q 13.3$ belong to the most frequently identified recurrent CNVs, and lead to mental retardation, seizures and minor dysmorphism. We report on two monozygotic twin boys with a mosaic $1.5 \mathrm{Mb}$ deletion in 15q13.3, including CHRNA7. The growth parameters were in the normal range for both twins. Both had language delay with hyperactivity, temper tantrums and poor social interaction but attended regular school. The percentage of abnormal cells was $40 \%$ on lymphocytes, and 25 and $35 \%$ on buccal smear in the first and second twins, respectively. The mosaicism for the 15q13.3 deletion can explain the milder phenotype observed in these two boys. 


\section{Introduction}

The use of array-CGH in large populations of individuals with intellectual disability and/or autism has demonstrated that clinically relevant CNVs accounted for a significant proportion of cases [1]. In the great majority of cases, these CNVs originate prezygotically and are identified in homogenous state in the affected individuals. However, in rare cases, the microrearrangements occur postzygotically, during the first mitotic divisions of the fertilized oocyte. These divisions are chromosomally unstable and can generate blastomeres with various numerical as well as structural chromosome abnormalities [2]. Depending on the distribution of blastomeres in the developing fetus, the chromosomal anomaly may be identified in homogenous or mosaic state. To date, evidence for mosaic microdeletions has been obtained pre or postnatally only for a very limited number of microrearrangement, including microdeletions in 16p11.2, 17p11.2p12, 22q11.2 or 22q13 [3-7].

Among recurrent CNVs, $15 q 13.3$ deletion is one of the most frequently identified microrearrangements. Classically, the $1.5 \mathrm{Mb}$ deleted region is located between the previously characterized breakpoints BP4-BP5 and contains 6 genes, including CHRNA7 (alpha-7 neuronal nicotinic acetylcholine receptor), but larger (between BP3-BP5) or smaller (including only the CHRNA7 gene) deletions were reported [8]. The phenotype associates mental retardation, seizures and minor dysmorphism. In most cases, the deletion is inherited from a carrier parent with a mild or no phenotype. To the best of our knowledge, this rearrangement has never been reported in a mosaic state. In this paper we report the first couple of twin boys presenting with a mosaic 15q13.3-q13.3 microdeletion involving the CHRNA7 gene. 


\section{Clinical description}

These MZ twin boys, born from the first pregnancy of a healthy 23 year-old mother and a 32 year-old unrelated father, were referred to our clinical genetics service for developmental delay. Family history was unremarkable. Delivery took place at 37 week gestation. Birth weights were 2.3 and $2.6 \mathrm{~kg}$, lengths 46.5 and $48 \mathrm{~cm}$ and head circumference 32.5 and $33 \mathrm{~cm}$. Both twins had a hypospadias. Motor milestones were in the normal range with walking achieved at 18 months. Language was delayed. Parents reported behavioral disturbances with hyperactivity, temper tantrums and poor social interaction. Boys attended regular school. On examination at age 6 years, growth parameters were in the normal range for both twins: height: $113 \mathrm{~cm}(\mathrm{M})$; weight: 19 and $20 \mathrm{~kg}$; head circumference: 51.5 and $52 \mathrm{~cm}$ (between M and -1SD). They exhibited striking facial resemblance with high and prominent forehead, deep set eyes, thin upper lip and large ears.

\section{Materials and Methods}

Conventional and molecular cytogenetic analyses were done on peripheral blood lymphocytes using standard techniques. The array-CGH analysis was performed on the high resolution whole-genome oligo-array SurePrint G3 Human CGH 4x180K Oligo Microarray Kit G4449A (Agilent Technologies, Massy, France) according to Agilent's protocol using DNA extracted from peripheral whole blood using a saline precipitation method. The data were processed using Agilent Feature Extraction and DNA Analytics softwares (both from Agilent Technologies), with the statistical algorithm ADM-2, sensitivity threshold 5 and at least 3 consecutive aberrant probes. 
The zygozity was assessed by genotyping of eleven microsatellite markers located on chromosomes 14 and 15, and by analysis of the 26 polymorphic CNVs identified by array-CGH in the two twins.

\section{Genomic rearrangement}

Conventional cytogenetic analysis by RHG banding showed a normal karyotype at the 550 bands resolution for both twins. The array-CGH analysis revealed a $1.5 \mathrm{Mb}$ microdeletion at 15q13.2 - q13.3 (Fig. 1A and B), ranging from genomic position $28,758,822$ to $30,226,176$ (first and last deleted probes, hg 18) and covering the CHRNA7 gene. The average value of the $\log _{2}$ ratio suggested the presence of a mosaic deletion, the proportion of cells with deletion being estimated between 30 and $40 \%$. The mosaicism was confirmed by metaphase FISH on cultured lymphocytes with BAC clone CTD-3242G24 (chr15:24,949,159-25,084,127, hg 18) covering the CHRNA7 gene, $40 \%$ of examined metaphases showing the deletion. To exclude a twin-to-twin blood transfusion, interphase FISH was performed on buccal epithelial cells, showing $35 \%$ and $25 \%$ cells with the deletion in the first and second twin, respectively. All identified structural polymorphisms and all analyzed microsatellite polymorphisms were shared by both twins, thus confirming the monozygozity.

\section{Discussion}

In this paper we report a couple of monozygotic twin boys with classical 15q13.2q13.3 deletion between BP4-BP5 involving the CHRNA7 gene in a mosaic state. 
CHRNA7 encodes the subunit alpha 7 of the neuronal cholinergic receptors, which are involved in synaptic transmission throughout the peripheral and central nervous system [9].

Our report provides new data concerning the mechanism and the timing of occurrence of the 15q13.3-q13.3 microdeletion. Regarding the mechanism, initially it was postulated that chromosomal rearrangements at the origin of recurrent microdeletion/microduplication syndromes occur in meiosis, mainly by a meiotic nonallelic homologous recombination (NAHR) mechanism. Later, the identification of mosaic cases in some microrearrangements pointed to another alternate mechanism, the postzygotic, mitotic NAHR. The frequency of mitotic NAHR is variable among different rearrangements, from very rare or anecdotal in some recurrent rearrangements such as microdeletions $16 \mathrm{p} 11.2,17 \mathrm{p} 11.2 \mathrm{p} 12,22 \mathrm{q} 11.2$ or $22 \mathrm{q} 13$ [37], to very frequent in the type 2 NF1 microdeletions, which are predominantly of postzygotic origin [10]. A survey of the literature using the key words "mosaic", "deletion" and "15q13" or "CHRNA7" failed to return any item. Thus, to the best of our knowledge, the present report is the first description of patients with mosaic $15 q 13.3$ deletion resulting by postzygotic NAHR.

Regarding the timing of occurrence of the 15q13.3-q13.3 microdeletion by the postzygotic NAHR, the identification of the same mosaic state in the monozygotic twins allows placing the NAHR occurrence on the embryonic developmental time scale. For years, it has been postulated that MZ twins are genetically identical and that phenotypic differences between twins are mainly due to environmental factors. There is an increasing body of evidence pointing to genetic differences between MZ twins, due to somatic mosaicism. These differences may explain at least in part the phenotypic differences. CNV differences are more frequent in phenotypically 
discordant twins but occur in concordant twins pairs [11]. At the opposite, in the present report both twins are clinically concordant and exhibit the same mosaic pattern, suggesting that the somatic recombination of polymorphic regions might have occurred at a relatively early stage in embryonic development. The twinning process occurs early in the development, the pattern of placentation being a reference mark for the time of cell mass splitting: if separation occurs before the first three days post fertilization the twins are dichorionic diamniotic, between three to nine days post fertilization monochorionic diamniotic, and, if splitting occurs after nine days post fertilization, monochorionic monoamniotic. The subsequent distribution of cellular clones among different tissues and organs in the twins may be similar or different, the twins being phenotypically concordant or discordant. In both twins the deletion was present in blood lymphocytes in a similar proportion, around of $40 \%$ of examined metaphases, but slight differences were observed in buccal smear. Unfortunately, we know neither the placentation pattern, nor the distribution of the abnormal cellular clone among the fetal annexes. Thus, to the best we only can suppose the occurrence of somatic NAHR before the eleventh-twelfth days post fertilization.

The heterozygous $15 q 13.3$ microdeletion is characterized by phenotypic variability ranging from a full phenotype, with seizures, developmental delay, and subtle facial dysmorphism, to an incomplete penetrance [12]. Homozygous deletion gives rise to a much more severe clinical picture, even in the case of the small deletion containing only the CHRNA7 gene, confirming the major role of this gene's haploinsufficiency in the phenotype. The case under report illustrates the milder end of the phenotypic spectrum, the two boys presenting the CNV in $40 \%$ of lymphocytes and showing a milder phenotype compared with the one usually observed in children carrying this 
microdeletion. However, the proportion of deleted cells may be different in neurons and any correlation between somatic mosaicism identified in lymphocytes and the severity of phenotype must be made with caution. In a case of $50 \%$ mosaic $7 q 31$ deletion involving FOXP2, the phenotype did not appear to be milder than in other reported cases [13]. Conversely, somatic mosaicism has also been reported in asymptomatic parents of children carrying deletions, such as in Kleefstra syndrome [14]. An increasing body of literature demonstrates the role of somatic mosaicism in sporadic diseases. Recently, in patients with segmental overgrowth disorders like Proteus syndrome, hemimegalencephaly and fibroadipose hyperplasia, somatic gainof-function mutations were identified in genes acting in the PI3K-AKT-mTOR pathway [15]. Although it is still too early to attempt to draw conclusions, at least in some situations it would seem that a relationship exists between the tissue mutation burden and the phenotype. In the same way, tissue specific presence of de novo somatic CNVs or large variations in the proportion of cell lines with or without a CNV among different tissues can explain the phenotypic discrepancies observed in some patients. Provided that the tissue material is available, array-CGH analysis is a powerful technique for identifying tissue-specific mosaicism for genomic imbalances from $10 \%$ abnormal cells [16].

In conclusion, this is the first report of mosaic $15 q 13.2-q 13.3$ deletion in monozygotic twins. The percentage of abnormal cells, between 25 and $40 \%$ in different tissues, can explain the milder phenotype observed in these two boys. However, due to the phenotypic variability observed among $15 q 13$ carriers, we cannot exclude that the milder phenotype observed in twins denotes the mild end of the clinical spectrum.

\section{Acknowledgements}


We thank the family members for their support. Part of this work was supported by the Direction Générale de l'Organisation des Soins (DGOS) from French Ministère des Affaires Sociales

et

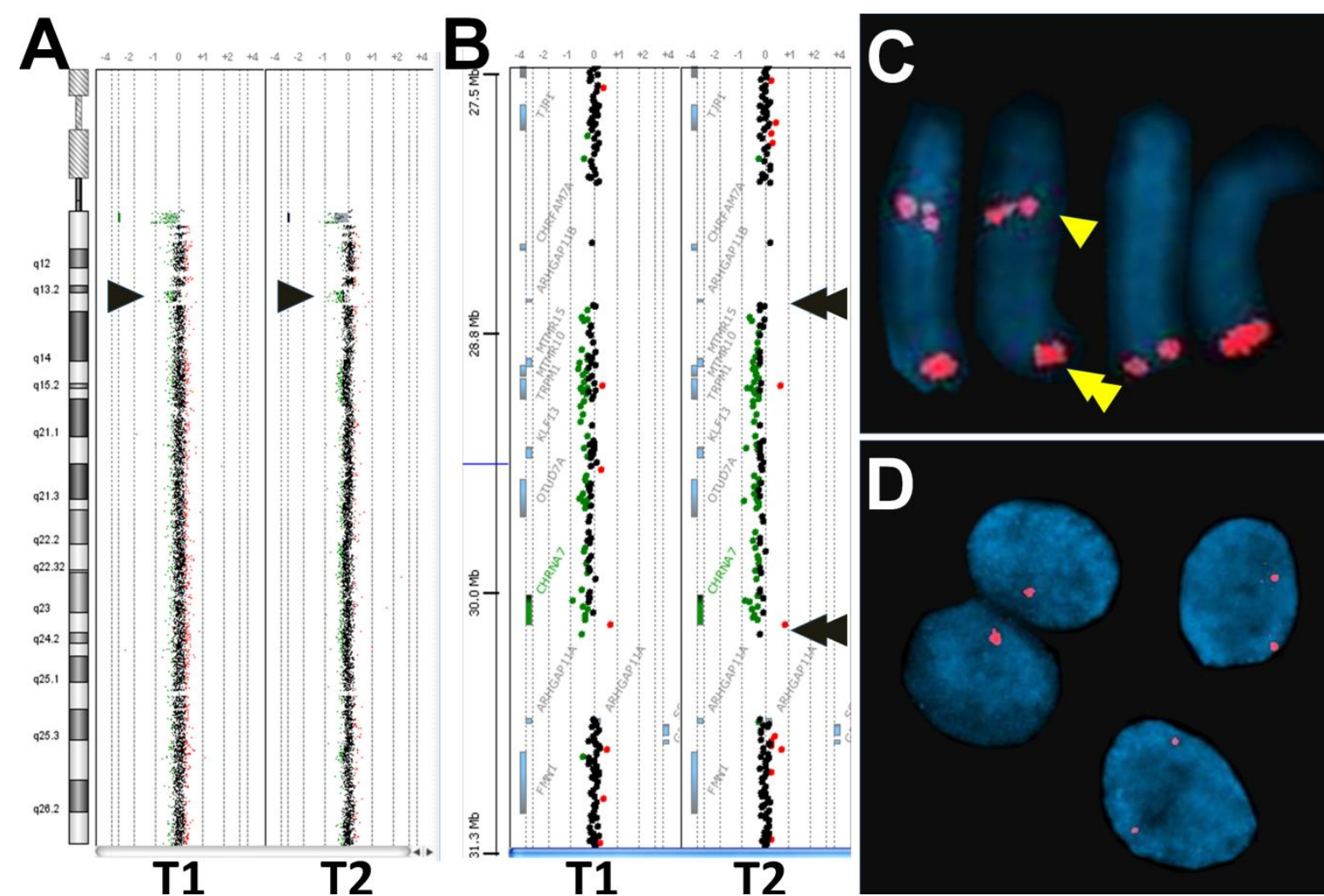

de la Santé. We are grateful to Dr. Martin Krahn for critically reviewing the manuscript.

Conflict of interest: None declared 


\section{References}

[1] Hochstenbach R, Buizer-Voskamp JE, Vorstman JA, Ophoff RA. Genome arrays for the detection of copy number variations in idiopathic mental retardation, idiopathic generalized epilepsy and neuropsychiatric disorders: lessons for diagnostic workflow and research. Cytogenet Genome Res. 2011; 135(3-4): 174202.

[2] Voet T, Vanneste E, Vermeesch JR. The human cleavage stage embryo is a cradle of chromosomal rearrangements. Cytogenet Genome Res. 2011; 133(2-4): 160-8.

[3] Zori RT, Lupski JR, Heju Z, Greenberg F, Killian JM, Gray BA, Driscoll DJ, Patel PI, Zackowski JL. Clinical, cytogenetic, and molecular evidence for an infant with Smith-Magenis syndrome born from a mother having a mosaic 17p11.2p12 deletion. Am J Med Genet 1993: 47 (4): 504-11.

[4] Chen CP, Chern SR, Lee CC, Lin SP, Chang TY, Wang W. Prenatal diagnosis of mosaic 22q11.2 microdeletion. Prenat Diagn 2004: 24 (8): 660-2.

[5] Dempsey MA, Schwartz S, Waggoner DJ. Mosaicism del(22)(q11.2q11.2)/dup(22)(q11.2q11.2) in a patient with features of 22q11.2 deletion syndrome. Am J Med Genet A 2007: 143A (10): 1082-6.

[6] Bonaglia MC, Giorda R, Beri S, Bigoni S, Sensi A, Baroncini A, Capucci A, De Agostini C, Gwilliam R, Deloukas P, Dunham I, Zuffardi O. Mosaic 22q13 deletions: evidence for concurrent mosaic segmental isodisomy and gene conversion. Eur J Hum Genet 2009: 17 (4): 426-33. 
[7] Shinawi M, Liu P, Kang SH, Shen J, Belmont JW, Scott DA, Probst FJ, Craigen WJ, Graham BH, Pursley A, Clark G, Lee J et al. Recurrent reciprocal 16p11.2 rearrangements associated with global developmental delay, behavioural problems, dysmorphism, epilepsy, and abnormal head size. J Med Genet 2010: 47 (5): $332-41$.

[8] Sharp AJ, Mefford HC, Li K, Baker C, Skinner C, Stevenson RE, Schroer RJ, Novara F, De Gregori M, Ciccone R, Broomer A, Casuga I et al. A recurrent 15q13.3 microdeletion syndrome associated with mental retardation and seizures. Nat Genet. 2008; 40(3): 322-8.

[9] Hogg RC, Raggenbass M, Bertrand D. Nicotinic acetylcholine receptors: from structure to brain function. Rev Physiol Biochem Pharmacol. 2003; 147: 1-46.

[10] Vogt J, Mussotter T, Bengesser K, Claes K, Högel J, Chuzhanova N, Fu C, van den Ende J, Mautner VF, Cooper DN, Messiaen L, Kehrer-Sawatzki H. Identification of recurrent type-2 NF1 microdeletions reveals a mitotic nonallelic homologous recombination hotspot underlying a human genomic disorder. Hum Mutat. 2012; 33(11): 1599-609.

[11] Bruder CE, Piotrowski A, Gijsbers AA, Andersson R, Erickson S, Diaz de Ståhl T, Menzel U, Sandgren J, von Tell D, Poplawski A, Crowley M, Crasto C, et al. Phenotypically concordant and discordant monozygotic twins display different DNA copy-number-variation profiles. Am J Hum Genet. 2008: 82(3): 763-71.

[12] van Bon BW, Mefford HC, Menten B, Koolen DA, Sharp AJ, Nillesen WM, Innis JW, de Ravel TJ, Mercer CL, Fichera M, Stewart H, Connell LE et al. Further delineation of the $15 q 13$ microdeletion and duplication syndromes: a clinical 
spectrum varying from non-pathogenic to a severe outcome. J Med Genet. 2009; 46(8): 511-23.

[13] Palka C, Alfonsi M, Mohn A, Cerbo R, Guanciali Franchi P, Fantasia D, Morizio E, Stuppia L, Calabrese G, Zori R, Chiarelli F, Palka G. Mosaic 7q31 deletion involving FOXP2 gene associated with language impairment. Pediatrics 2012; 129(1): e183-8.

[14] Willemsen MH, Beunders G, Callaghan M, de Leeuw N, Nillesen WM, Yntema HG, van Hagen JM, Nieuwint AW, Morrison N, Keijzers-Vloet ST, Hoischen A, Brunner HG et al. Familial Kleefstra syndrome due to maternal somatic mosaicism for interstitial 9q34.3 microdeletions. Clin Genet. 2011; 80(1): 31-8.

[15] Lindhurst MJ, Sapp JC, Teer JK, Johnston JJ, Finn EM, Peters K, Turner J, Cannons JL, Bick D, Blakemore L, Blumhorst C, Brockmann K et al. A mosaic activating mutation in AKT1 associated with the Proteus syndrome. N Engl J Med. $2011 ; 365(7): 611-9$

[16] Repnikova EA, Astbury C, Reshmi SC et al. Microarray comparative genomic hybridization and cytogenetic characterization of tissue-specific mosaicism in three patients. Am J Med Genet A 2012: 158A (8): 1924-33. 


\section{Figure Titles and Legends}

Figure 1. Array-CGH analysis in monozygotic twin boys ( $T 1$ and $\mathrm{T} 2$ ) showing (A) whole chromosome $15 \log _{2}$ plot with the mosaic 15q13.2-q13.3 deletion (arrowhead) and (B) zoom in of the 15q13.2-q13.3 deleted region (the limits of the deleted region are marked by double arrowheads). The imbalance was confirmed by metaphase FISH analysis on lymphocytes with BAC probe CTD-3242G24 corresponding to the CHRNA7 gene (arrowhead) and TelVysion 15q probe (double arrowhead) (C) and by interphase FISH analysis on buccal smear with BAC probe CTD-3242G24 (D).

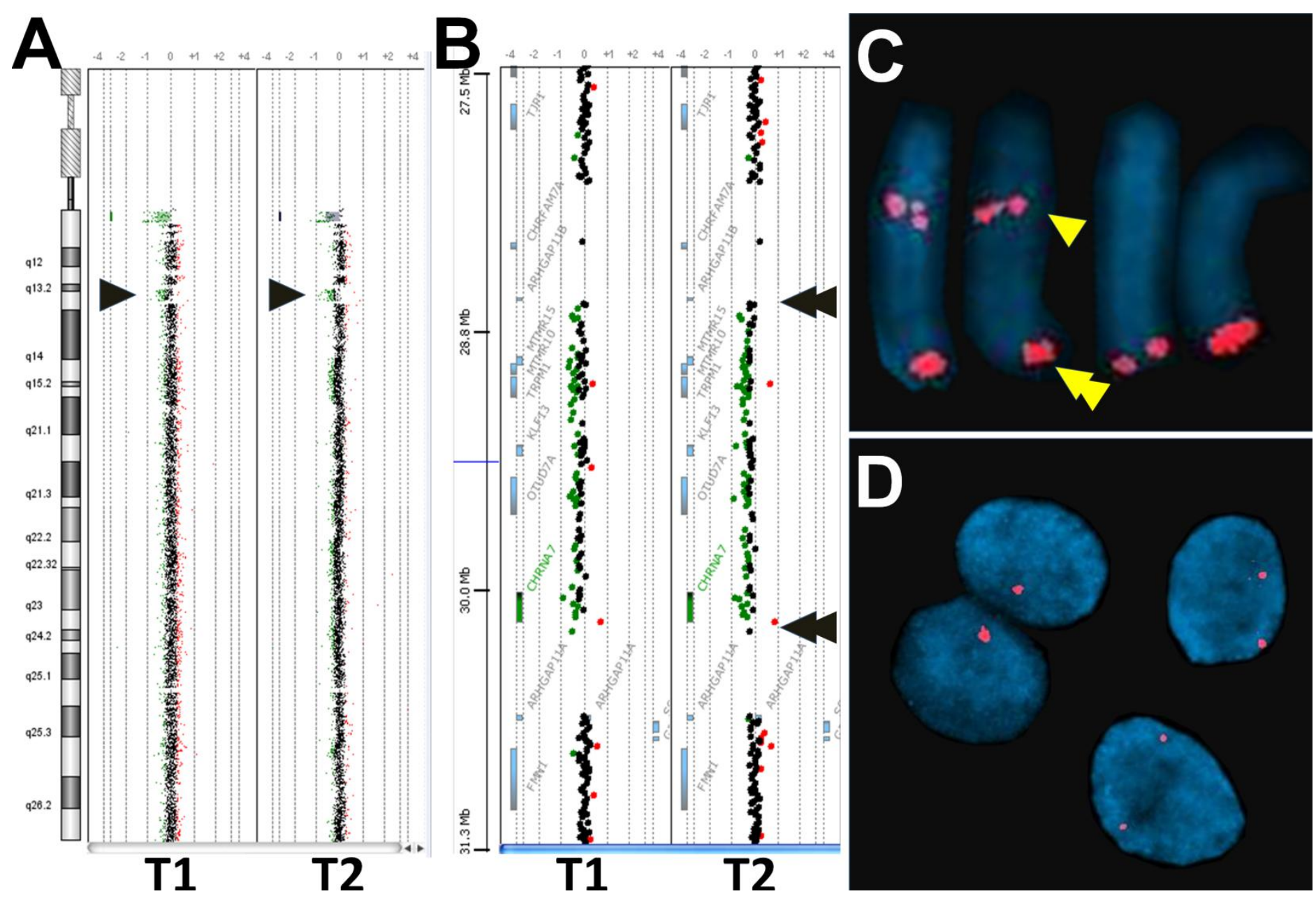

